\title{
Efficiency and fuel specific consumption of an engine running on fish biodiesel
}

\author{
Otávia Lídia Klaus*, Lucas Villetti, Jair Antonio Cruz Siqueira, Samuel Nelson Melegari de \\ Souza, Reginaldo Ferreira Santos, Carlos Eduardo Camargo Nogueira and Cassiano Rosseto
}

\author{
State University of the West of Paraná, 2069, CEP: 85.819-130. Bairro Faculdade, Cascavel-PR, Brazil.
}

Accepted 14 October, 2013

\begin{abstract}
Brazil is a country whose agricultural and agroindustrial activity has grown considerably. In fish processing, there is the availability of residual fat, which when transesterificated originates fish biodiesel, which can replace diesel oil as a fuel in diesel engines. In this study, the aim was to evaluate the performance of an engine generator set (by Branco), with a power of $7.36 \mathrm{~kW}(10 \mathrm{hp})$ coupled to a generator of $5.0 \mathrm{~kW}_{\mathrm{e}}$ using $100 \%$ fish biodiesel (B100) and $20 \%$ pure biodiesel (B20) in comparison to the pure diesel (B0). Assays were performed by varying the load of the generator. Results show that, the performance of the engine generator set using B100 is higher than that with B0, for a maximum test load of $2.6 \mathrm{~kW}$. An overall efficiency of the engine generator set of $21.6 \%$ was found for the load of 2.6 kW.
\end{abstract}

Key words: Energy, biofuel, electricity, biomass.

\section{INTRODUCTION}

The Brazilian territory has a huge extension and its climate is conducive to agro industrial activities because it is a country with great potential for exploration of the biomass for food, chemical and energy purposes, and therefore to produce biodiesel (Feltes et al., 2010).

Brazil has fishing potential as few countries in the world due to the amount of marine and continental waters. The use of fish fat to make biodiesel is an alternative to the energy matrix, as well as other raw materials such as vegetable oils, animal fats, and others (Martins, 2012).

Biodiesel is a renewable biofuel and can be used in four-stroke diesel cycle engines without major complications, replacing mineral diesel, being the biodiesel conducted as the primary fuel fish biodiesel (B100) or added to diesel oil (Neto et al., 2000).

In the production of biodiesel, the main stage is the transesterification, which according to Knothe et al. (2006) is the only process by which one can obtain the products commonly called biodiesel (methyl and ethyl esters). In the process, the material of animal origin (triacylglycerols) is reacted with methanol in the presence of a catalyst, and the result is glycerol (by-product) and methyl ester (biodiesel), which is refined in the separation and ester purification phases.

The production of biodiesel based on residual fat from the fish processing farms is an alternative to the production by means of vegetable oils and contributes to decrease the use of arable lands for the production of oilseeds for energy purposes, allowing such areas to be used for the cultivation of food.

The use of residual fat from fish processing helps to meet the need for new raw materials for biofuel production, and also solves the environmental problem entailed by the waste generated from the processing of fish, bringing economic and sustainable benefits for fish farming (Kulkarniv and Dalai, 2006).

In this study, the aim was to compare the performance of an engine generator set (brand: Branco), with a power 


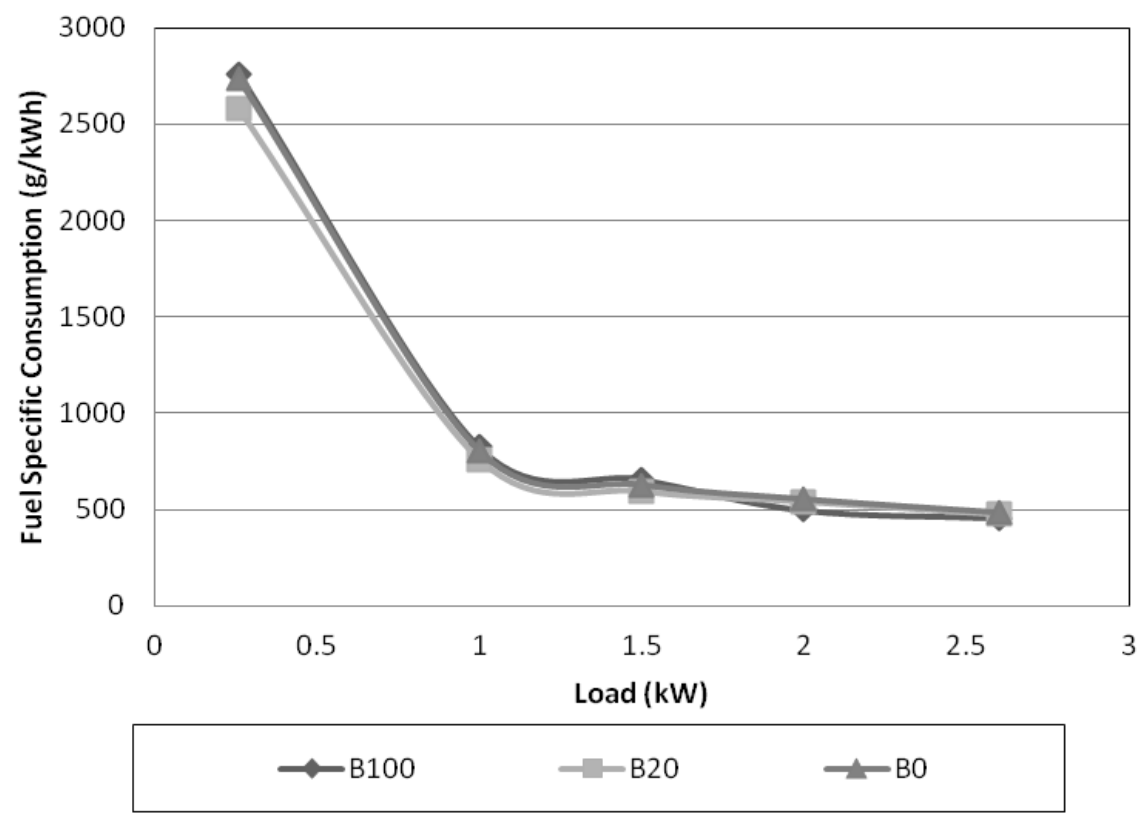

Figure 1. Specific fuel consumption according to the load for mixtures B20, B0, and B100.

of $7.36 \mathrm{~kW}(10 \mathrm{hp}$ ) and $5.0 \mathrm{kWe}$ generator running on B100, pure diesel (B0), and pure biodiesel (B20), $20 \%$ biodiesel mixed to mineral diesel.

\section{MATERIALS AND METHODS}

The study was conducted at the Western Paraná State University, Paraná, Cascavel, Brazil. In order to determine the performance, a $7.36 \mathrm{~kW}(10 \mathrm{hp})$ cycle diesel engine generator set, model BD $6500 \mathrm{CF}$ with $5.0 \mathrm{kWe}$ nominal power, with an output voltage of $120 / 240 \mathrm{~V}$ single phase running on fish biodiesel was used.

The biodiesel used in this study was produced by transesterification from residual fats from fish farms in Western Paraná, Brazil. Samples with volumetric composition between biodiesel and mineral diesel were prepared in the proportions $0 \%$ (B0), 20\% (B20), and 100\% biodiesel (B100) and used in the assay. The fuel consumption of the engine generator set $(\mathrm{kg} / \mathrm{s})$ was obtained by a precision scale and a stopwatch, by varying the engine's load by means of a bank of electrical resistances $(0.3,1$, $1.5,2$, and $2.6 \mathrm{~kW}$ ).

Performance evaluation of the set is based on the specific fuel consumption (SFC) and conversion efficiency ( $\eta$ ) in the electricity in the engine generator set. Equation 1 was used in the determination of the specific fuel consumption.

$\mathrm{SFC}=\frac{3,6 \cdot 10^{3} \times \mathrm{xC}}{\mathrm{Car}}$

In which, SFC is the specific fuel consumption, $\mathrm{g}^{\mathrm{kWh}}{ }^{-1}$, Car is the load of electrical resistance (kW) and FC is the fuel consumption $\left(\mathrm{kg} . \mathrm{s}^{-1}\right)$.

The efficiency of the engine generator set was obtained by means of Equation 2:

$\eta=\left(\frac{3600}{\operatorname{ICVXSFC}}\right) \times 100$
In which $\eta$ is the efficiency of the set (\%) and ICV is the low heating value (MJ.kg ${ }^{1}$ ).

High heating value of the fuel samples was obtained by means of a calorimeter model E2k and the low heating valuewas obtained by the methodology of Volpato et al. (2009), which takes the high heating value into account.

\section{RESULTS AND DISCUSSION}

Figure 1 presents the behavior of the SFC of the engine generator set according to the load applied to the generator. One could observe that, the SFC is higher for loads lower than $1.0 \mathrm{~kW}$.

Regarding the $20 \%$ blend of biodiesel, the most significant result was given to the rated load of $2.6 \mathrm{~kW}$, in which the SFC was $473.6 \mathrm{~g} \mathrm{kWh}^{-1}, 1.5 \%$ less than 480.9 $\mathrm{g} \mathrm{kWh}^{-1}$, which corresponds to the SFC of BO. In other words, B20 showed lower consumption when compared to pure diesel. The consumption of pure biodiesel (B100) presented a value of $457 \mathrm{~g} \mathrm{kWh}^{-1}$ with the load of $2.6 \mathrm{~kW}$, $5 \%$ lower than the SFC of B0. Data showed that for a higher load fish biodiesel contributes to lower fuel consumption.

For smaller loads between 0.3 and $1.5 \mathrm{~kW}, \mathrm{~B} 100$ has higher specific consumption in comparison with the B0 and B20. This comes against the study of Castellanelli et al. (2008) which showed that, viscosity difference between biodiesel and diesel oil is also an important factor in the SFC, causing poor atomization as well as an incomplete burning of fuel at low and medium speeds.

Results found for the low heating value of biodiesel, 


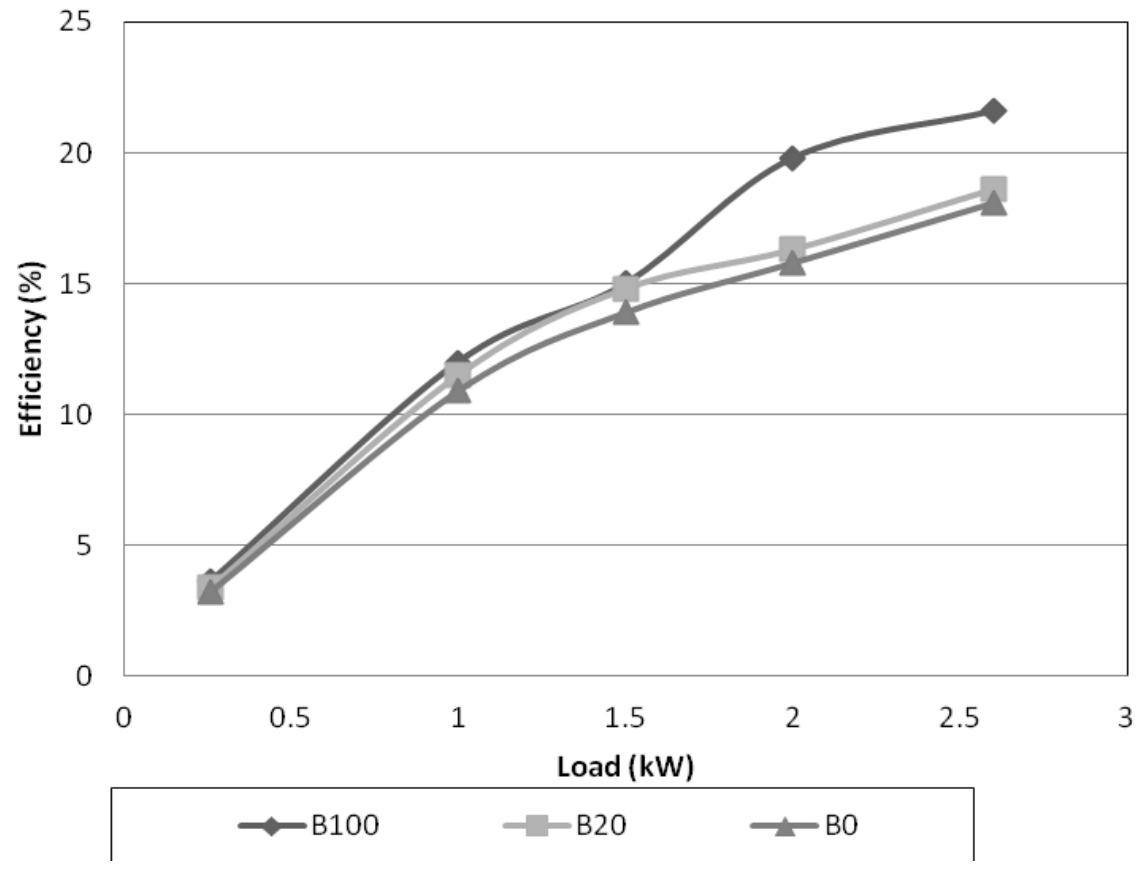

Figure 2. Efficiencyof the engine generator set according to mixture and load.

according to the method of Volpato et al. (2009) were 41.26 $\mathrm{MJ} \mathrm{kg}^{-1}$ for B0, 40.99 $\mathrm{MJ} \mathrm{kg}^{-1}$ for B20, and 36.52 MJ $\mathrm{kg}^{-1}$ for B100. In a characterization study of diesel and biodiesel, Neto et al. (2000) found that, the low heating value measured for diesel oil was $42.30 \mathrm{MJ} \mathrm{kg}^{-1}$ as the ICV for biodiesel from soybean oil used for frying was $37.50 \mathrm{MJ} \mathrm{kg}^{-1}$, such results are similar to those obtained in this study for fish biodiesel.

One may observe in Figure 2 that, the behavior of the engine generator set running on B0 and B20 followed by a similar trend with efficiency to a maximum load of $18 \%$, whereas B100 from $1.5 \mathrm{~kW}$ showed an efficiency higher than B0 and B20, achieving an efficiency of $21.6 \%$ at a load of $2.6 \%$. These results show once more that, the performance of the engine with pure fish biodiesel (B100) is greater at higher loads. It was observed that, mixture B20 and B100 have better performance when compared to pure diesel (B0).

\section{Conclusion}

The performance of the engine generator set was superior when running on fish biodiesel (B100), showing an efficiency of $21.6 \%$ for a maximum test load of $2.6 \mathrm{~kW}$. Specific consumption at a load of $2.6 \mathrm{~kW}$ was greater when only diesel was used, $480.9 \mathrm{~g} . \mathrm{kWh}^{-1}$. However, fish biodiesel (B100) showed SC of $5 \%$ lower than that of diesel (B0).

Thus, fish biodiesel being used in an engine generator set has proved to have good performance.

\section{REFERENCES}

Castellanelli M, Souza SNM, Silva SL, Kailer EK (2008). Performance cycle diesel engine on a dynamometer bench using mixtures diesel biodiesel. Revista Brasileira de Engenharia Agrícola 28(1):145-153.

Feltes MMC, Correia JFG, Beirão LH, Block JM, Ninow JL, Spiller VR (2010).Alternatives to adding value to the fish processing industry wastes. Revista Brasileira de Engenharia Agrícola e Ambiental 14(6):669-677.

Knothe G,Gerpen JV, Krahl J, Ramos LP (2006). Manual Biodiesel. Edgard Blücher 340 pp.

Kulkarniv MG, Dalai AK (2006). Waste cooking oil - an economical source for biodiesel: A review. Ind. Eng. Chem. Res. 45(9):29012913.

Martins GI (2012).Potential extraction of fish oil for biodiesel production. Dissertation, Universidade Estadual do Oeste do Paraná, Paraná, Brasil.

Neto PRC, Rossi LFS, Zagonel GF, Ramos LP (2000). Biofuel production as an alternative to diesel oil by transesterification of soybean oil used for frying Revista Química Nova 23(4):532-537.

Volpato CES, Conde AP, Barbosa JA, Salvador N (2009). Performance four-stroke diesel engine fed with biodiesel from soybean oil (B 100). Revista Ciência e Agrotecnologia 33(4):1125-1130. 